急速に末期腎不全へ進行するループス腎炎の臨床的検討

\begin{tabular}{llllll}
\multicolumn{5}{c}{ 杏林大学医学部第一内科学教室 } \\
吉田 & 雅治 $\diamond$ & 斉藤 & 元章 & 过 & 正人 \\
有村 & 義宏 & 副島 & 昭典 & 井上 & 明夫 \\
中林 & 公正 & 北本 & 清 & 長沢 & 俊彦
\end{tabular}

\title{
CLINICAL STUDIES ON RAPIDLY PROGRESSIVE END STAGE RENAL FAILURE IN PATIENTS WITH LUPUS NEPHRITIS
}

Masaharu YoshiDA, MD, Motoaki SAITo, MD, Masato TsujI, MD, Yoshihiro ARIMURA, MD, Noriaki SoEJIMA, MD, Akio INoue, MD,

Kimimasa NAKABAYASHI, MD, Kiyoshi KITAMOTo, MD and Toshihiko NAGASAWA, MD

The First Department of Internal Medicine, School of Medicine, Kyorin University, Mitaka, Tokyo

\begin{abstract}
概要 最近我々が経験した，母疾患であるSLEの発症と同時に，あるいは堅症が発現してから 数年以上経過してから，急速に腎不全が進行して末期腎不全に陥つたループス腎炎（RPLN） 11例の臨床所見之検査所見の特徴について検討した．その結果，発症時から堅機能の低下が著 しく，1 月月以内に死亡した 3 例 (Group I, hyperacute RPLN) と，約 1 カ月間のネフロー セ症候を経過してRPLNへ進行し，約 1 カ月後に腎外症状により死亡した 3 例(Group II, acute RPLN)，および持続性蛋白尿ないし血尿の時期を $1 〜 3$ 年経過した後に，短期間のネブーゼ 症候を経てRPLNに進行した 5 例（Group III, accelerated RPLN) の3 群に分類された。組 轼学的には, 全例管内性增殖性病変と同時に, 半月体形成腎炎の像を呈し,さらにGroup Iの 3 例は細動脈のフィブリノィド型血管炎を伴つていた，検查所見上，血清補体の著明な低下，血 中免度複合体 (CIC) レベルの上昇および中〜大分子量サイズのIC活性の存在, 凝固線溶元進状 態との共通した特徽を示した。このような急激な経過をとらないようにするためには，検査所 見の特徵から早期に本病型を診断し，SLEの免疫学的活動性を允分に抑制することが最も重要 である、不幸にしてこのような状態を生じた場合には免疫抑制療法に抗凝固線溶療法を併用し， かつ適切な時期に透析治療を導入することが臨床上極めて重要と思われた。
\end{abstract}

\section{緒 垔}

ループス腎炎(以下LNと略す)の予後は，近年 全身性エリテマトーデス（以下SLEと略す）自身 の診断率の向上に伴うLNの早期発見と免疫抑制

[昭和59年 9 月 21 日受稿〕

本論文の要旨恃第26回日本腎臓学会総会（1983年10月， 京都)扣よび第28回日本りウマチ学会総会(1984年 5 月, 京）において発表した。
療法の徹底により著しく向上した ${ }^{1) \sim 4)}$. しかし、一 方では末期腎不全に進行し，透析治療の導入を余 儀なくされるLNが少なからず存在することる確 かな事実である516)，最近，我々は母疾患である SLEの発症と同時に，あるいは腎症が発現してか ら数年以上経過してから，急速に腎不全が進行し て末期腎不全に陥つたLN 11例を経験したので， これらの症例の臨床所見と検查所見を分析した。 
その結果これらの症例に共通した特徽的な所見 のあることを見出したので，その詳細について報 告する。

\section{対象症例と検索方法}

1. 対象症例：LNが発症してからの期間は 問わず，数週から数カ月の短期間でそれまで保た れていた腎機能が急速に低下して，BUN，血清ク レアチニン（以下Cr）の著しい上昇をきたして透 析治療を導入しない限り確実に腎不全死に至る症 例を，急速に末期腎不全に進行するループス堅炎 (rapidly progressive lupus nephritis, 以下RPLN と略す）と定義し，この基準にあてはまらずに持 続性蛋白尿/血尿(以下PPと略す)，高度の腎機能 低下を伴わないネフローゼ症候（以下NSと略 す)，执よ゙慢性腎炎症候(きわめて徐々に腎機能 が低下し，高血王や軽い浮腫など，腎炎症候を呈 する例)を示すLNを一括してnon-RPLNとした。 対象はRPLN 11例で, non-RPLN 28例を対照症 例とした。

2. 検索方法：一般的な検查所見(検血，検尿， 血液生化学など）の他に，以下の項目について検 討した。

1) 免疫学的検查. (1)抗ds-DNA抗体； radioimmunoassay法により測定した。正常值は10U/ ml以下である。(2)血清補体；CH50はMeyerの $50 \%$ 溶血法, C3 ( $\beta_{1} \mathrm{C} / \beta_{1} \mathrm{~A}$ globulin), C4 ( $\beta_{1} \mathrm{E}$ globulin) はsingle radial immunodiffusion法によ り測定した．正常値はCH50が30〜 40U/ml, C3は $70 \sim 130 \mathrm{mg} / \mathrm{dl}, \mathrm{C} 4$ は20〜 40mg/diである. (3)血中 免疫複合体 (circulating immune complex, 以下 $\mathrm{CIC}$ と略す）： Raji細胞免疫蛍光法7に上り測定 した. 正常値は0〜 $4 \mu \mathrm{g} / \mathrm{ml}$ である. (4)CICサイズ ; CIC陽性例のサイズ別IC活性をsepharose CL 6B あるいはsephacryl S-300カラムを用いたゲル沪 過法により分析し，各分画のIC活性値を分子量 (以下MWと略す) 別にsmall size (以下 (S) と略 す): $\mathrm{MW} \leqq I g G$, middle size (以下 (M) と略 す): MW IgG〜IgM, large size (以下 (L) と

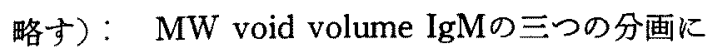
分けて表現しだ。
2）凝固線溶系検查. (1)血中および尿中FDP； latex法による「FDPLキット」にて測定した。正 常值は, 血中FDPが $0 \sim 10 \mu \mathrm{g} / \mathrm{ml}$, 尿中FDPが $1 \sim 2$ $\mu \mathrm{g} / \mathrm{ml}$ 以下である. (2)plasminogen (以下PLgと略 す), anti-thrombin III (以下AT-III と略す), $\alpha_{2}$ plasmin-inhibitor (以下 $\alpha_{2}$-PIと略す) をそれぞれ テストチームキットにて，合成基質法で測定し， 正常值は活性值としてそれぞれ80〜100\%で表現 した。

3) 腎組織検查. 11症例中 8 例(剖検 7 例，生検 1 例) の腎組織光光顕 (HE, PAS, PAM染色), 执よび免疫虽光法（抗ヒト IgG, IgM, IgA, C3, C4, fibrinogen染色)により観察した。一部症例では電 鰂的観察む行なつた.

\section{成 續}

\section{1. 臨床経過および転归}

Fig 1にRPLN 11例のLN発症時からRPLNに 至る臨床経過を，Table 1にRPLN 11例の治療执 ょび転帰を一括して示した（なお，成績の項で文 中, 表, 図に用いた臨床症候の略語は, Fig 10下 段に一括して示した，又，†は死亡例を示す。）.

以下，11例をLNの発症からRPLNへ致るまで の期間により三つの群に分類して述べる.

(1) Group I (hyperacute RPLN)

症例1. YT, 16才，女子. 全身の関節痛, 筋肉 痛, 蛋白尿で発症. 初診時より腎機能低下があり, プレドニンロン(以下PSLと略す) $40 \mathrm{mg} /$ 日の投与 を開始したが，RPLNに移行，黄色連鎖球菌によ

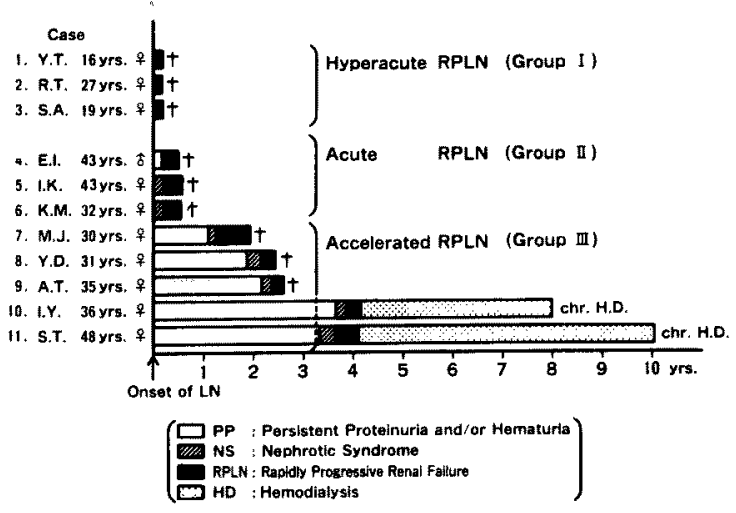

Fig 1. Clinical course of RPLN $(n=11)$ 
Table 1. Outcome and Treatments of 11 Patients with RPLN.

\begin{tabular}{|c|c|c|c|c|c|c|c|}
\hline & \multirow{2}{*}{$\begin{array}{l}\text { Steroid therapy } \\
\text { PSL } \geq 60 \mathrm{mg} /\end{array}$} & \multirow{2}{*}{ Pulse therapy } & \multirow{2}{*}{$\begin{array}{l}\text { Immunosuppresive } \\
\text { drugs }\end{array}$} & \multicolumn{2}{|c|}{ Hemopurification } & \multirow{2}{*}{ Outcome } & \multirow{2}{*}{ Causes of Deoth } \\
\hline & & & & H.D. & Plaums Exchasoge & & \\
\hline $\begin{array}{r}\text { Group } 1 \text { Casel } \\
2 \\
3\end{array}$ & $\begin{array}{l}- \\
- \\
+\end{array}$ & $\begin{array}{l}- \\
- \\
-\end{array}$ & $\begin{array}{l}- \\
- \\
-\end{array}$ & $\begin{array}{l}- \\
- \\
-\end{array}$ & $\begin{array}{l}- \\
- \\
-\end{array}$ & $\begin{array}{l}\text { Died } \\
\text { Died } \\
\text { Died }\end{array}$ & $\begin{array}{l}\text { Sopsis } \\
\text { CNS-Lupus } \\
\text { CNS-Lupus }\end{array}$ \\
\hline $\begin{array}{r}\text { Group II Cased } \\
5 \\
6\end{array}$ & $\begin{array}{l}+ \\
+ \\
+\end{array}$ & $\begin{array}{l}+ \\
+ \\
+\end{array}$ & $\begin{array}{l}- \\
+ \\
+\end{array}$ & $\begin{array}{l}+ \\
+ \\
+\end{array}$ & $\begin{array}{l}+ \\
+ \\
+\end{array}$ & $\begin{array}{l}\text { Died } \\
\text { Died } \\
\text { Died }\end{array}$ & $\begin{array}{l}\text { G.I. Bleeding } \\
\text { Pneumonitis } \\
\text { G.I. Bloeding }\end{array}$ \\
\hline $\begin{array}{r}\text { Group II Case7 } \\
8 \\
9\end{array}$ & $\begin{array}{l}+ \\
- \\
+\end{array}$ & $\begin{array}{l}+ \\
+ \\
-\end{array}$ & $\begin{array}{l}- \\
-\end{array}$ & $\begin{array}{l}+ \\
+ \\
-\end{array}$ & $\begin{array}{l}- \\
- \\
-\end{array}$ & $\begin{array}{l}\text { Died } \\
\text { Died } \\
\text { Died }\end{array}$ & $\begin{array}{l}\text { G.I. Bleeding } \\
\text { Pneumonitis } \\
\text { CNS-Lupus }\end{array}$ \\
\hline $\begin{array}{l}10 \\
11\end{array}$ & $\begin{array}{l}+ \\
+\end{array}$ & $\begin{array}{l}+ \\
+\end{array}$ & $\begin{array}{l}- \\
-\end{array}$ & $\begin{array}{l}+ \\
+\end{array}$ & - & $\begin{array}{l}\text { Alive } \\
\text { Alive }\end{array}$ & $\begin{array}{l}\text { On Chr. H.D.) } \\
\text { On Chr. H.D.) }\end{array}$ \\
\hline
\end{tabular}

る敗血症を合併し，敗血症性ショックにて死亡し た。

症例 2.RT，27才，女子 SLEの発症と同時に RPLNを呈し, PSL 30mg/日の投与が行なわれた が，中权神経性ループス(以下CNS-lupusと略す) によると思われる痊挛発作を頻回に起こして死亡 した.

症例 $3 . \mathrm{SA}, 19$ 才，女子 上気道感染後，約 1 週間で高血圧, 乏尿, 高空素血症が出現し, PSL $100 \mathrm{mg} /$ 日， つパリン $10000 \mathrm{U} /$ 日の投与を開始した が, 症例 2 と同様に頻回の疹率発作を起こして, 発症後 1 週間で死亡した。この群の代表例として 臨床経過をFig 2に示す．検查所見上BUN 110 $\mathrm{mg} / \mathrm{dl}, \mathrm{Cr} 7.4 \mathrm{mg} / \mathrm{dl}$ と上昇, 血小板数は 4.6 万/ $\mathrm{mm}^{3}$ と减少, 血中FDPは $40 \mu \mathrm{g} / \mathrm{ml}$ と上昇, PLg
73\%，AT-III 58\%と凝固線溶え進状態を示し，さ らにCH50が $12 \mathrm{U} / \mathrm{ml}, \mathrm{C} 34 \mathrm{mg} / \mathrm{dl}, \mathrm{C} 42 \mathrm{mg} / \mathrm{dl}$ と著 明な低補体血症括よびCICが $380 \mu \mathrm{g} / \mathrm{ml}$ と高值を 示した。

小括：以上 3 例は，SLE発症と同時にきわめ て短期間で末期腎不全に陥入り，診断を確定して steroid治療や血液浄化法などを計画的に施行す る以前に, 腎外症状により 1 力月以内に死亡した。 このGroup Iの 3 例は臨床経過が超急性であるの で, hyperacute RPLN と称した。

(2) Group II (acute RPLN)

症例 4.EI，43才，男子。 NSを呈し，PSL 60 $\mathrm{mg}$ /日投与を開始して，1 力月後にRPLNに移行 した。 パルス療法, 透析治療, 血桼交换を施行し たが，約 1 力月後に急性消化管出血を起こして死

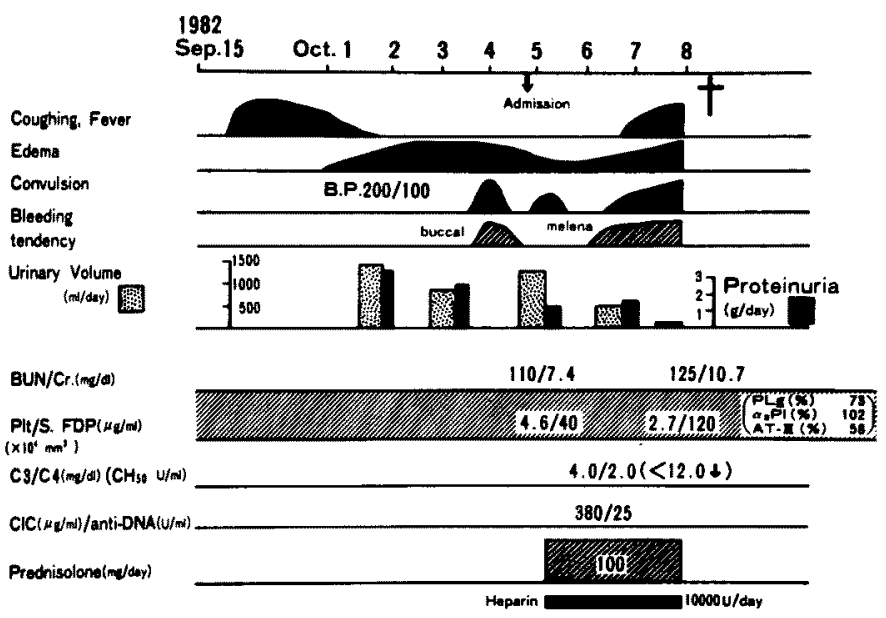

Fig 2. Case 3. S.A. 19yrs. 우 Hyperacute RPLN. 
亡した。

症例 5，IK，43才，女子．尿蛋白 $15 \mathrm{~g} /$ 日，BUN $60 \mathrm{mg} / \mathrm{dl}, \mathrm{Cr} 3.5 \mathrm{mg} / \mathrm{dl}$ と $\mathrm{NS}$ 同時に中等度の腎 不全を呈して当科に緊急入院し，入院後血清免疫 検查により初めてLNと診断された。この群の代 表として臨床経過をFig 3に示す.ただちに，血浆 交換とパルス療法を含むステロイド大量投与を開 始したが，約 1 力月後BUN $123 \mathrm{mg} / \mathrm{dl}, \mathrm{Cr} 8.7 \mathrm{mg} /$ dl とRPLNに移行した. そこで，再び血浆交換，透 析治療，パルス療法を含むPSL大量投与を行なつ たところ，透析治療を離脱することに成功した。

しかし，NSは持続したのでPSLとサイクロホス ファミドの併用を続けたところ，肺炎を合併して 死亡した。検査所見上Fig 3に示すように, RPLN 発症時に血小板数が 5.6 万 $/ \mathrm{mm}^{3}$ と減少, 血䌽FDP $60 \mu \mathrm{g} / \mathrm{ml}$ と上昇し, 低補体血症, CIC高値を示し た.

症例 6. KM, 32才, 女子 大量蛋白尿, 浮腫々 NSの状態で発症してから約 1 力月後に, RPLN に移行した。ハハルス療法を含むPSL大量投与，免 度抑制剤，血液透析，血浆交換を行なつたが，約 2 力月後に肺炎を合併して死亡した。

小括：以上 3 例は，SLE発症 1 年以内に短期 間のNS期を経てRPLNに進行した症例で，いず れも計画的に免疫抑制療法と血液浄化法が行なわ れたか，腎外症状により死亡した．Group IIの 3 例はGroup I息どではないが，急性の臨床経過を
とつているので, acute RPLNと称した.

(3) Group III (accelerated RPLN)

症例 7.MJ, 30才, 女子 約 1 年間PPを呈し, 他施設でPSL 15 30mg/日の投与が行なわれて いた. 次第にNSに移行し,さらにRPLNへ進行し たため当科に転院した。たたちに血液透析を導入 し，その後パルス療法を含むPSL大量投与を行な つたが, 約 2 カ月啳に急性消化管出血で死亡した.

症例 8.YD, 31 才。女子. PPが約 2 年間続き， これに対してPSL 10〜30mg/日の投与が行なわ れたが, 漸次NSとなり，さらにRPLNに進行した ため当科に転院となつた。たたちに血液透析を導 入し，バルス療法を含むPSL大量投与を行なつた が, 䄪 2 カ月後に急性消化管出血で死亡した.

症例 9.AT，35才，女子 PPに対して他施設で, 非ステロイド系消炎剤の投与が行なわれていた が，約 2 年後にNSとRPLNを呈したため当科に 入院した。ただちにPSL大量投与を開始したが， 著明な血小板减少を呈し，透析治療を導入する前 に脳出血を合併して死亡した。

症例10.IY, 36才, 女子. PPが約 3 年間続きPSL 投与量が $10 \mathrm{mg} /$ 日に减量された時点で，NSから RPLNへ進行した。この群の代表としてFig 4に 臨床経過を示す。パルス療法を含むPSL大量投 与, ウロキナーゼ大量療法を施行したが, 腎不全 の進行を阻止することができず血液透析を導入乙 た，その後，透析を離脱することはできなかった

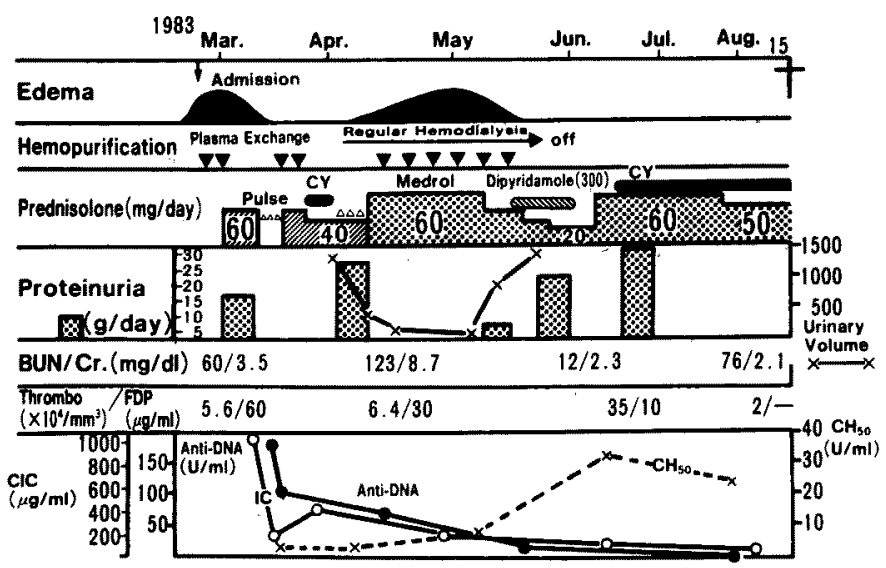

Fig 3. Case 5. I.K. 43yrs. ㅇ Acute RPLN. 


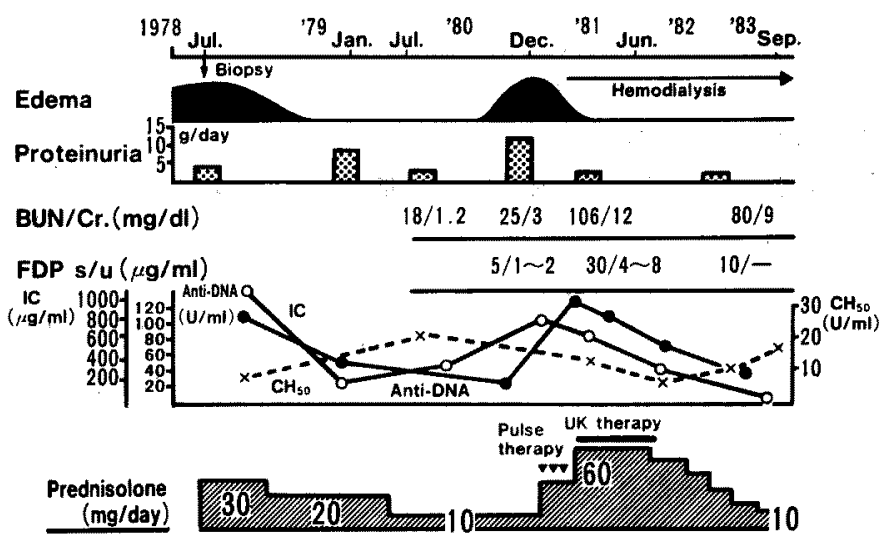

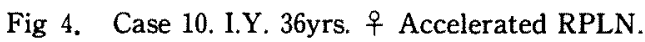

が，PSL投与量は10mg/日まで咸量することがで き, 透析導入 4 年後の今日, 週 3 回の定期透析を 行ないながら社会復州している.

症例11.ST，48才，女子．他施設でPPを呈した LNとして, PSL 5 20mg/日の投与が 3 年半行な われていたが，NSからRPLNへと進行して当科 入院となつた。ただちに血液透析を導入し，パル ス療法を含むPSL大量投与を行なつたところ，尿 量は保つたまま蛋白尿は減少し，NSは不完全寛 解II型にまで改善したが，BUN，Crの上昇は持続 し，血液透析を離脱することはできなかつた。し かし, 透析導入後 6 年半たつた今日, PSL $7.5 \mathrm{mg} /$ 日の維持量投与で社会復帰している。

小括： 以上 5 例は, PPの時期を $1 \sim 3$ 年経過 した後で, Group II 同様に短期間のNS期を経 て，RPLNに進行した症例である．5ち症例 7 ,
8,9 の 3 例は, PSL大量投与, 血液浄化法を勢力 的に施行したが寛解がみられず，いずれも腎外症 状により死亡した。症例10，11の 2 例は，PSLの 維持量 (7.5 10mg/日)の投与と慢性透析を施行 中である．以上のGroup IIIの 5 例はLNとして慢 性に経過中加速的にRPLNを生じたといら意味 でaccelerated RPLN と称した。

\section{2. 腎組織所見}

RPLN 8例（Group Iの症例 1, 2, Group IIの 症例 4,5, Group IIIの症例 7-8，9は剖検腎, Group IIIの㱏例10は生検腎)の腎組織を検索した 成績を, Table 2に一括して示す. 光顕所見上, 全 例にほぼ全周性の半月体形成が認められ，かつ管 内性变化として膜性増殖性腎炎Type Iにみられ るよらな, 基底膜の二重構造, 内皮下沈着物（wire loop病変),メサンギゥム細胞と基質の増殖, 一部

Table 2. Renal histology of 8 patients with RPLN.

\begin{tabular}{cc|ccccc}
\hline & \multicolumn{5}{|c}{ WHO Classification } \\
\cline { 2 - 6 } & $\begin{array}{c}\text { Double } \\
\text { Contour }\end{array}$ & $\begin{array}{c}\text { Subendothelial } \\
\text { deposits }\end{array}$ & $\begin{array}{c}\text { Cellular } \\
\text { cresents }\end{array}$ & $\begin{array}{c}\text { Hyaline } \\
\text { thrombi }\end{array}$ & Angitis \\
\hline Group I & Case1. Y.T & - & + & + & + & + \\
\cline { 2 - 7 } & Case2. R.T. & + & + & + & + & + \\
\hline Group II & Case4. EI. & + & + & + & - & - \\
\cline { 2 - 7 } & Case5.1.K. & + & + & + & - & - \\
\hline \multirow{2}{*}{ Group III } & Case7.M.J. & + & + & + & + & - \\
\cline { 2 - 7 } & Case8. Y.D & + & + & + & - & - \\
\cline { 2 - 7 } & Case9. A.T. & - & + & + & + & - \\
\cline { 2 - 7 } & Case10. I.Y. & + & + & + & - & - \\
\hline
\end{tabular}




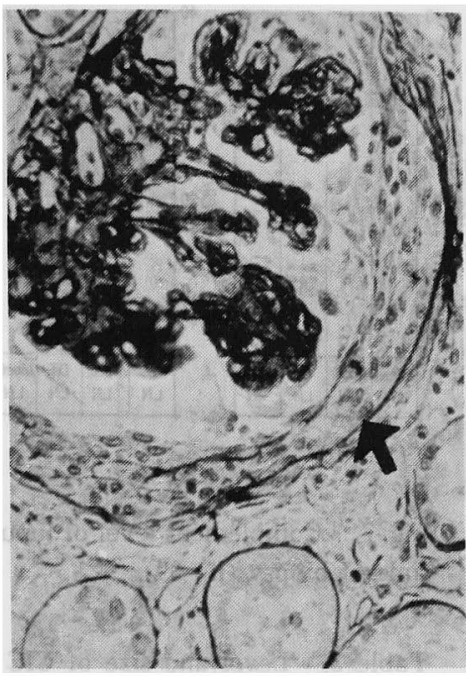

(A)

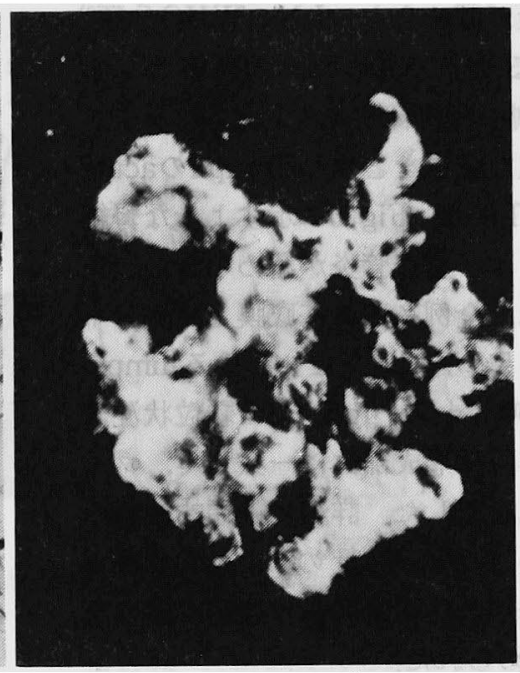

(B)

(A) PAS staining $(\times 200)$ showing crescentic glomerulonephritis (arrow) with endocapillary proliferation.

(B) Anti-human-IgG FITC staining $(\times 200)$ showing intensive deposits of IgG.

Fig 5. Case 8, A.T. (Group III, autopsied kidney)

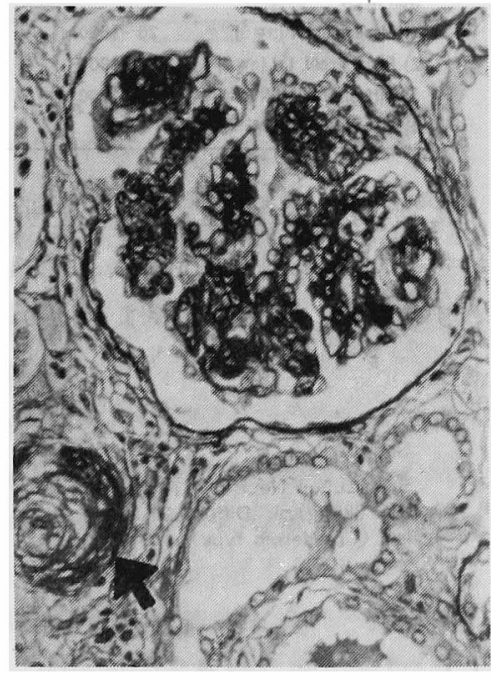

(A)

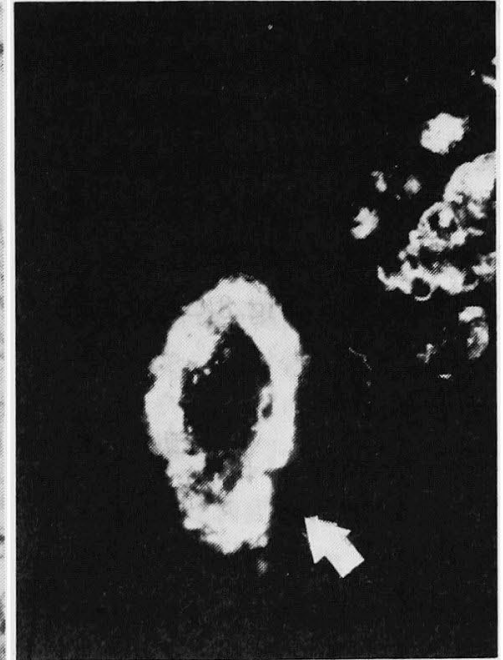

(B)

(A) PAS staining $(\times 200)$ showing arteriolar fibrinoid necrosis (arrow)

(B) Anti-human-IgG staining $(\times 400)$ showing intensive IgG deposits in the vascular wall (arrow).

Fig 6. Case 2, R.T. (Group I, autopsied kidney) 
の例で硝子様血栓が認められ，LNのWHO分類9) のIV型に相当する所見であつた. 代表例として Group IIIのAT例の腎組織所見をFig 5に示す. 又,きわめて急速な経過をとつたGroup Iのacute RPLNの症例，RT例は，Fig 6に示すような腎細 動脈のフィブリノイド型血管炎が認められた。免 疫営光所見上では, 全例系球体基底膜とメサンギ ウム領域に, Fig 5に示すようないわゆるlumpybumpy pattern と呼ばれる, IgG, C3の顆粒状沈着 を認めた，又，半月体形成部位に一致して，フィ ブリンが陽性所見を呈した。詳細に電顕的観察の できた 3 例でいずれも大量の subendothelial depositを認め, 一部の症例では糸球体基底膜の断 裂像（gap）も認められた。

\section{3. 免疫学的所見}

1）血清補体：Fig 7k RPLN 8例 と nonRPLN 28例のCH50，C3，C4値を組織病型別 (WHO分類)に示す. RPLNの血清補体は, CH50, C3, C4のいずれもnon-RPLNに比較して有意に低 い値を呈していた（ $\mathrm{p}<0.05$, t検定）.

2）血中免疫複合体 (CIC)：Table 3 K RPLN 7例, non-RPLN 14例のCICの值を組織病 型別に示す. 全例CICは陽性で, non-RPLNのうち membranous LNを除くと，RPLNとnon-RPLN との間で，CICレベルに著しい差異は見出されな かつた．次にCICサイズについてみてみると， RPLNのうちGroup Iの 2 例は, Fig 8に示すよう
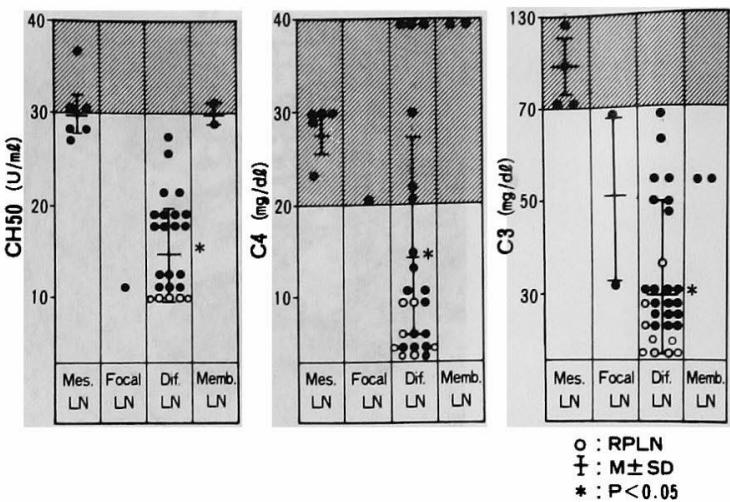

Fig 7. Complement level of lupus nephritis at the time of biopsy $(n=39)$.

Table 3. Level and size of CIC in patients with lupus nephritis $(n=21)$

\begin{tabular}{|c|c|c|c|c|}
\hline \multirow{2}{*}{ Type of $L N$} & \multirow{2}{*}{$\begin{array}{c}\text { CIC } \\
\text { level } \\
\text { (Raji IF, } \mu \mathrm{g} / \mathrm{ml})\end{array}$} & \multicolumn{3}{|c|}{ CIC Size } \\
\hline & & $\begin{array}{c}\text { Small } \\
<\lg G, \lg G\end{array}$ & $\begin{array}{c}\text { Middle } \\
\text { IgG IgM }\end{array}$ & $\begin{array}{l}\text { Large } \\
\text { IgM< }\end{array}$ \\
\hline \multicolumn{5}{|l|}{ RPLN } \\
\hline Group I $(n=3)$ & $100 \sim 500$ & ++ & \# & $\#$ \\
\hline II $(n=4)$ & $>1000$ & $+\#$ & \# & - \\
\hline III & & & & \\
\hline \multicolumn{5}{|l|}{ Non RPLN } \\
\hline 1) Mesangial $L N(n=5)$ & $20 \sim 1500$ & $+\#$ & - & - \\
\hline 2) Focal Prolif. $L N(n=2)$ & $>1000$ & $+H$ & + & - \\
\hline 3) Diffuse Prolif. LN $(n=4)$ & $>1000$ & $+H$ & \# & - \\
\hline 4) Membranous LN $(n=3)$ & $5 \sim 50$ & ++ & \# & + \\
\hline
\end{tabular}

に，(M)および(L) 領域にICサイズの活性が認め られた。一方, Group II, IIIの 4 例は，Fig 9に示 すように，CICサイズは（S）が主体で一部 (M)

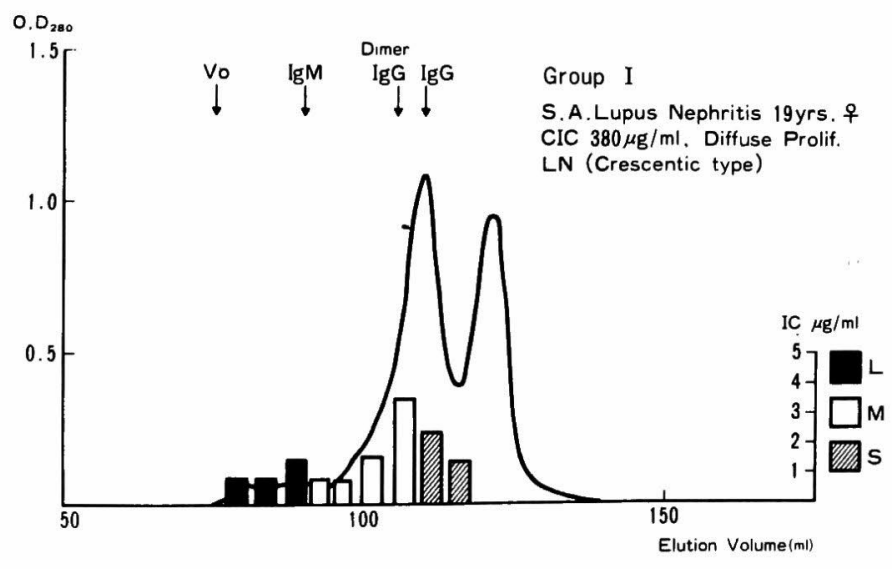

Fig 8. Sepharose C.L. 6B Separation of test sera and CIC. 


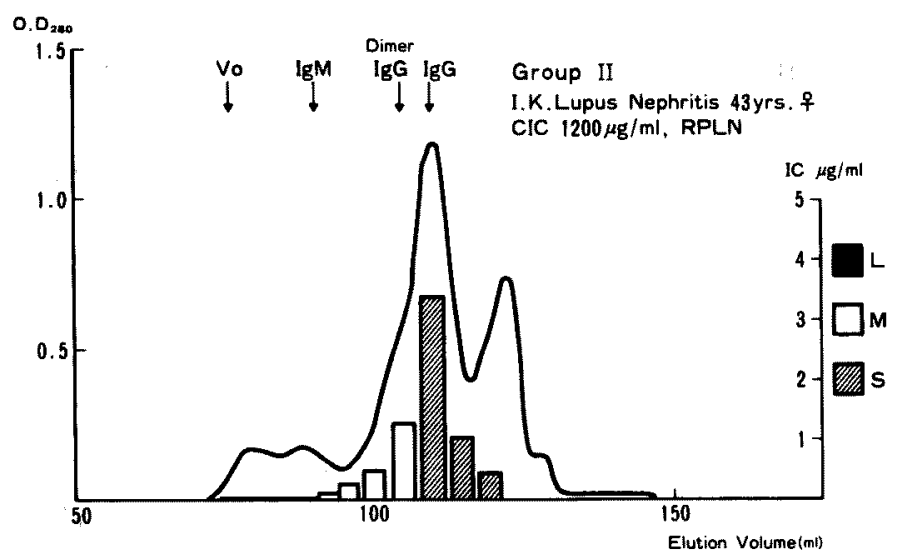

Fig 9. Sepharose C.L. 6B Separation of test sera and CIC.

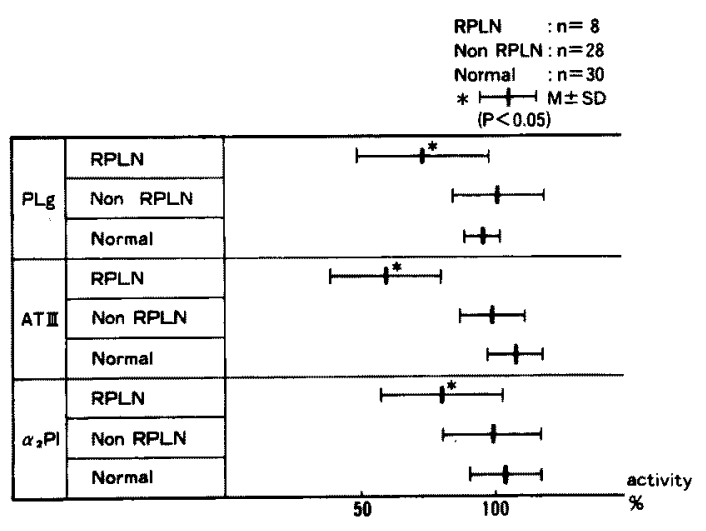

Fig 10. The Levels of PLg, AT-III, $\alpha_{2} \cdot \mathrm{Pl}$ in patients with lupus nephritis $(M \pm S D)$.

領域にも存在した.

\section{4. 凝固線溶系検查}

RPLN 8例, non-RPLN 28例就よび健常人30例 のPLg, AT-III, $\alpha_{2}$-PIの平均值 $(\mathrm{M} \pm \mathrm{SD}) を \mathrm{Fig} 10$ に示す. RPLNでは, non-RPLNに比較して, PLg, AT-III， $\alpha_{2}$-PIのいずれも有意に低下を示し（p< 0.05 , t検定), 凝固線溶元進状態にあることが明ら かにされた。 なお, RPLNの発症時に血小板数は, 11 症例中 7 例で 10 万 $/ \mathrm{mm}^{3}$ 以下の低值を示した。

\section{考 案}

緒言で述べたように，LNに対して充分な免疫 抑制療法が施行されている今日に拈いてる，末期 腎不全に速やかに進行し，透析療法の導入を余儀 なくされるRPLNが存在することが注目されて
いる5)6)このRPLNを呈するLNは, 透析導入後 1 年以内に 8 40\%が透析から離脱できる半面, 16 40\%が死亡する予後不良の病型である占610). 今回我々の経験したRPLN 11例は，LNの発症か らRPLNに到るまでの期間により三つの群に分 けることがでさた。

すなわち, Group I（症例 1，2，3）：SLE発 症と同時にRPLNを呈し，診断を確定し計画的な 免疫抑制寮法や血液浄化法を施行する以前に全て 1 力月以内に死亡したhyperacute RPLN. Group II（症例 4, 5,6）：Group I注ど超急性ではな いが, LN発症後 1 年以内に 1 力月程度のNS期を 必ず経てRPLNへ進行し，血液浄化法の施行と同 時に免疫抑制療法が行なわれたが，腎外症状によ り約 1 カ月後に死亡したacute RPLN. Group III (症例 7 11)：PPの時期を $1 \sim 3$ 年と長期間 経過した後で, Group II と同様に短期間のNS期を 経て，RPLNに進行した。この群は慢性に経過中， RPLNに転化したという意味で accelerated RPLNと称した. Group Iは本質的にはGroup II と 同じ群として扱らこともできたが，Group Iは発 症より死亡をでの期間が 1 力以内と短かく， SLEの診断が下されることなく，したがつて系統 的な治療を実施する以前に活動期SLEの腎外症 状によつて死亡した点が，Group IIと異なる事情 を勘案して，一応Group IIと別に分類することと した. なお，Group I, IIのRPLNを発症させた誘 
圀ついては，臨床経過上り特定の因子は見出せ なかつた。一方，Group IIIではRPLN移行への triggerとして，PPの時期のステロイド治療が計 画的に行なわれていないか, 又は患者の自己判断 によつて服用を中止したり，減量したりしている ことをあげることができる。

我々の経験したRPLN 11例のらち9 例が死亡 し，予後はきわめて不良であつた。死因は感染症 3 例, CNS-lupus 3 例, 急性消化管出血 3 例であ つた. 最近のSLEの死因は多因化し, Stevenら ${ }^{11}$, 市川ら ${ }^{12)}$ の指摘しているょうに，感染症，CNSlupus, 心血管系疾患，消化管出血と腎外症状によ るものが多いとされ，我々のRPLN 9例の死因む 全てこれら腎外因子によるすのであつた。 今後, RPLNを呈するLNには, 腎外蔵器障害に対する 対索を含めた全身的管理が肝要と思われた。次に RPLN 11例中 8 例に腎の組織学的検索を行なつ たが，これら全例に共通している光顕所見は，管 内性には采球体基底膜の二重構造と内皮下沈着物 を認めた，すなわち，膜性増殖性変化を呈し，さ らに管外性に細胞性半月体形成を呈していたこと である。さらに興味あることにGroup Iのhyperacute RPLNでは, 細動脈のフィブリノイド型血 管炎が認められた。免疫喾光法では，管内性に免 疫グロブリンと補体成分の多量の沈着之，管外性 にフィブリンの沈着が認められ，びまん性ループ ス腎炎(WHO分類IV型)に特徵的な所見を呈して いた。これらの形態所見と臨床所見を照らし合わ せると, Group Iでは発症時からこのような管内 性・管外性病変を同時に呈し，LNの腎組織所見上 予後不良の徵候の一つとされる血管炎所見 ${ }^{13)}$ 伴 い, 病像の進行を促進させたるのと推定された。 一方Group II, IIIでは管内性変化のみの時期が続 いた後に，管外性変化が急に加わつてきたすのと 推定することができる，このよらな管外性変化を もたらした原因は何であろらか，Fig 10に示すよ うに，RPLNを呈した時期には全身的に㠜固線溶 六進状態がみられたので, 当然糸球体内凝固異常 る亢進し，血栓形成，あるいはフィブリンの漫出 による半月体形成を招いたるのと考皇られる。
Fig 7に示すようにRPLNを呈した時期には全例 低補体血症を示して扣り，さらにTable 3に示す よらにCICは高值を示した。これらの事実はSLE の免疫学的活動性九進が，凝固線溶系の異常を惹 き起こしたものと推定できる.Reganら ${ }^{14} /$ は, SLE の活動性の亢進に伴う補体結合性免疫複合体は, 血小板との相互作用を介して凝固線溶系を進さ せるとしており，RPLNの発症機序の推定の上 で,これら血清補体， CIC と凝固線溶系の関連の追 求は重要であり，今後さらに検討が必要と思われ た.さらにTable 3に示すよらに, RPLNのCICを total として測定するのみでなく，そのサイズを分 析したところ, Group Iのhyperacute RPLNは， CICサイズが (M) および (L) 分子量領域のmacromolecular ICに活性が存在し，他のGroup II, IIIのRPLN敊よび，non-RPLNは（S）サイズが主 体であり明らかな差異を認めた。今回の検索より， CICレベルにサイズ分析を加えることは，RPLN の発症時期の推定に，臨床的に有用と思われた。 最近, Kimberly $ら^{(0)}$, Coplan $ら^{15}$ は透析に導入さ れるLN (以下end stage LNと略す) の検査所見 上，血清補体等のSLEの免疫学的活動性は，透析 離脱群と，死亡群および慢性透析群で有意差はな いとしているが，今回の我々の成績はこれらと注 ぼ同様の結果であつた。

次に治療について考察してみると，LNで最も 予後の悪いRPLNを生ぜしめないためには, SLE の免疫学的活動性を適切にcontrolすることが最 も重要なことと思われる. Group III accelerated RPLNはいずれも，PPの時期のステロイド治㞠が 適切でなかつた。一方, RPLNがー旦発症してし まつた場合には，事情の許す限りへパリン，ウ口 キナーゼなどによる抗凝固線溶療法を免疫抑制療 法に加える必要があり，また時期を失しないよう 血液透析を導入することが重要である6)，透析治 療の導入により全身状熊を改善させることは，大 量の免疫抑制薬使用に基づく合併症を生ずる頻度 を確実に減少させるものといえる。一方，血浆交 換は 3 例に実施し，弓ち 1 例は透析療法離脱に成 功したが，残り 2 例については劇的な効果をあげ 
ることができなかつた：LNに対する血浆交換の 適応と有用性については，なお今後症例数を増し ての検討が必要と思われた ${ }^{16)}$.

最後に, LN症例で血清補体の低下，CICレベル の上昇括よびmacromolecular size ICの存在, 凝 固線溶六進状態といら共通した臨床検査所見を認 めた場合には，RPLNへの移行を疑つて早期に適 切な妈置を講ずることが，LNの臨床上重要であ ることを強調したい。

\section{結論}

SLEの発症と同時に，あるいはLNの経過中に RPLNに進行したLN 11例の，臨床経過，腎組織 所見，免疫異常，凝固線溶系異常について報告し た. RPLNに対しては，免废抑制療法に加えて抗 凝固線容療法の併用，および適切な時期に透析治 療を含めた血液净化法の導入が肝要であると思わ れた。

謝辞 厚生省進行性腎障害調查研究班および自己免疫疾 患調查研究班の研究費の援助をらけたことを感謝する。

\section{文献}

1）本間光夫，他：SLEの臨床経過と治療，厚生省特 定先患膠原病治療調查研究班（班長 本間光夫）, 昭和 56 年度研究業績, $1982, \mathrm{p} 301$.

2）橋本博史，塩川優一：過去10年間に診断された全 身性エリテマトーデスの自然歴に関する研究．日 内会誌 $71: 1546,1982$.

3) Wallace DJ, et al: Systemic lupus erythematosus survival patterns. Experience with 609 patients. JAMA $245: 934,1981$.

4) Wallace DJ, et al: Lupus nephritis-Experience with 230 patients in a private practice from 1950 to 1980. Amer J Med 72: 209, 1982.

5) Kimberly RP, et al: End-stage lupus ne- phritis. Clinical course to and outcome in dialysis. Medicine $60: 277,1981$.

6）長沢彸彦，北本 清：膠原病透析症例の全国調查 成績，厚生省特定疾患膠原病治療調査研究班（班 長 本間光夫)，昭和56年度研究業積，1982，p79.

7) 吉田雅治：Raji細胞免疫蛍光法による血中免疫福 合体定量法の開発とルーブス堅资における血中兔 疫複合体定量の臨床的意義。日内会誌 $68: 1089$, 1979.

8）吉田雅治, 木村常雄, 他：ループス堅炎の血中兔 疫複合体サイズと糸球体組織病型との関保。日焣 会誌 $24: 873,1982$.

9) Churg J and Sobin LH: Lupus nephritis. Renal disease-Classification and Atlas of Glomerular Diseases. Igaku-shoin, Tokyo Japan, 1982, pl28.

10) Kimberly RP, et al: Reversible end-stage lupus nephritis. Amer J Med 74:361, 1983.

11) Steven $R$, et al: A multicenter study of outcome in systemic lupus erythematosus. 1. Causes of death. Arthritis Rheum $25: 612,1982$.

12）市川陽一, 他：SLEの死因について，第28回日本 リウマチ学会総会，予稿集，1984，p68.

13) Bhuyan UN, et al : Prognostic significance of renal angitis in systemic lupus erythematosus (SLE). Clin Neph $20: 109,1983$.

14) Regan MG, et al: Platelet function and coagulation profile in lupus erythematosus. Studies in 50 patients. Ann Intern Med $81: 462$, 1974.

15) Coplan NS, et al: The long term clinical course of systemic lupus erythematosus in endstage renal disease. New Engl J Med $308: 186$, 1983.

16) Yoshida $M$, et al : Plasma exchange for lupus nephritis. Therapeutic plasmapheresis (III). Edited by T Oda, K Schattauer, Verlag. Stuttgart, NY, 1984, p312. 